\title{
Zoogeography of Elasmobranchs in the Colombian Pacific Ocean and Caribbean Sea
}

\author{
Andrés Felipe Navia, Paola Andrea Mejía-Falla and José Sergio Hleap
}

In order to investigate zoogeographical patterns of the marine elasmobranch species of Colombia, species richness of the Pacific and Caribbean and their subareas (Coastal Pacific, Oceanic Pacific, Coastal Caribbean, Oceanic Caribbean) was analyzed. The areas shared 10 families, 10 genera and 16 species of sharks, and eight families, three genera and four species of batoids. Carcharhinidae had the highest contribution to shark richness, whereas Rajidae and Urotrygonidae had the greatest contribution to batoid richness in the Caribbean and Pacific, respectively. Most elasmobranchs were associated with benthic and coastal habitats. The similarity analysis allowed the identification of five groups of families, which characterize the elasmobranch richness in both areas. Beta diversity indicated that most species turnover occurred between the Coastal Pacific and the two Caribbean subareas. The difference in species richness and composition between areas may be due to vicariant events such as the emergence of the Isthmus of Panama. It is unlikely that the Colombian elasmobranch diversity originated from a single colonization event. Local diversification/speciation, dispersal from the non-tropical regions of the Americas, a Pacific dispersion and an Atlantic dispersion are origin possibilities without any of them excluding the others.

Para conocer los patrones zoogeográficos de los elasmobranquios marinos de Colombia, la riqueza de especies de Pacíico y Caribe y sus subáreas (Pacífico costero, Pacífico oceánico, Caribe costero y Caribe oceánico) fue analizada. Las áreas compartieron 10 familias, 10 géneros y 16 especies de tiburones y ocho familias, tres géneros y cuatro especies de batoideos. Carcharhinidae tuvo la mayor contribución a la riqueza de tiburones mientras que Rajidae y Urotrygonidae tuvieron la mayor contribución a la riqueza de batoideos en el Caribe y el Pacífico, respectivamente. La mayoría de los elasmobranquios estuvieron asociados con hábitats bénticos y costeros. El análisis de similitud permitió la identificación de cinco grupos de familias que caracterizan la riqueza de elasmobranquios en ambas áreas. La diversidad beta indicó que el mayor recambio de especies se produjo entre el Pacífico costero y las dos subáreas del Caribe. La diferencia en la riqueza y composición de especies entre las áreas puede ser debida a eventos vicariantes tales como el surgimiento del Istmo de Panamá. Es poco probable que la diversidad de elasmobranquios en Colombia se originara de un único evento de colonización. Eventos locales de diversificación/especiación, dispersión desde las regiones templadas de América, del Pacífico y del Atlántico son orígenes posibles que no se excluyen entre sí.

Keywords: Batoids, Beta diversity, Historical biogeography, Richness, Sharks, Vagility.

\section{Introduction}

Despite the high diversity of elasmobranchs (more than 465 species of sharks and 539 batoids), grouped in 178 genera and 51 families (Nelson, 2006; White \& Last, 2012; Dulvy et al., 2014), there are few zoogeographical studies carried out in this group, and most are focused on the order Rajiformes (Ishihara, 1991; Last \& Yearsley, 2002; Musick et al., 2004; Last \& White, 2011). Elasmobranchs are distributed in all the world oceans, from the poles to tropical waters, and from the surface to over 3,000 $\mathrm{m}$ depth. Many species have circumglobal distribution, but most are restricted to a specific geographical area (McEachran \& Aschliman, 2004; Musick et al., 2004).
Dispersal in elasmobranchs depends on active swimming of individuals, contrary to most teleost fishes, in which it occurs by means of eggs and larvae. Dispersal is then closely linked to vagility, which is in turn inversely correlated with speciation (Bush, 1975), taxa diversity (Hrabik et al., 2005) and endemism (Anderson, 1994). Specifically for sharks, it is proposed that the species vagility is directly proportional to body size, with oceanic species more able to disperse than coastal ones (Musick et al., 2004). Also, it has been suggested that vicariant events, such as the Pangea breakup, played a decisive role in the evolution of distribution patterns currently observed in some benthic sharks (Musick et al., 2004). For batoids, and based on the proposal that their fossil record date from the late Jurassic to Paleocene

Fundación Colombiana para la Investigación y Conservación de Tiburones y Rayas, SQUALUS. Carrera 60A 11-39, Cali, Valle del Cauca, Colombia. (AFN) anavia@squalus.org, (PAM-F) pmejia@squalus.org, (JSH) jshleap@squalus.org 
(Cappetta, 1987), the observed distribution patterns should reflect the Gondwana partition during the final period of the Mesozoic Era (Pielou, 1979; Hallam, 1981; Pitman III et al., 1993; Last \& Yearsley, 2002).

Colombian marine and freshwaters contain 128 species (64 sharks and 64 batoids; Mejía-Falla et al., 2007, 2011; Lasso et al., 2013). Most studies on elasmobranchs in Colombia have been directed towards biology (e.g. MejíaFalla et al., 2012, 2014a; Grijalba-Bendeck et al., 2012; Payán et al., 2011), ecology (e.g. Navia et al., 2007, 2010, 2011; López-García et al., 2012; Mejía-Falla \& Navia, 2011; Mejía-Falla et al., 2014b), fisheries (Acevedo et al., 2007; Grijalba-Bendeck et al., 2007), genetics (Hleap et al., 2012), and only Díaz (1984) carried out a zoogeographical study of sharks in the Colombian Pacific. The goal of this manuscript was to investigate zoogeographical patterns of the marine elasmobranch fauna of Colombia, and hypothesize its origin and affinity with other geographic regions.

\section{Material and Methods}

Based on the latest elasmobranch checklist of Colombia (Mejía-Falla et al., 2007) and specific additions to elasmobranch richness (Mejía-Falla et al., 2011), a database with the distribution of each species in the marine waters of Colombia (Pacific Ocean and Caribbean sea) was constructed. Since most records do not indicate the exact location of collection or capture, it was assumed that the presence of a species is continuous between its most extreme records. For those species with a single known record, that location was considered the single point of distribution of that species. Since the analyzed waters correspond to both oceanic and coastal environments, four subareas were considered when analyzing the richness and distribution of the elasmobranchs: coastal Caribbean, oceanic Caribbean, coastal Pacific and oceanic Pacific (Fig. 1).

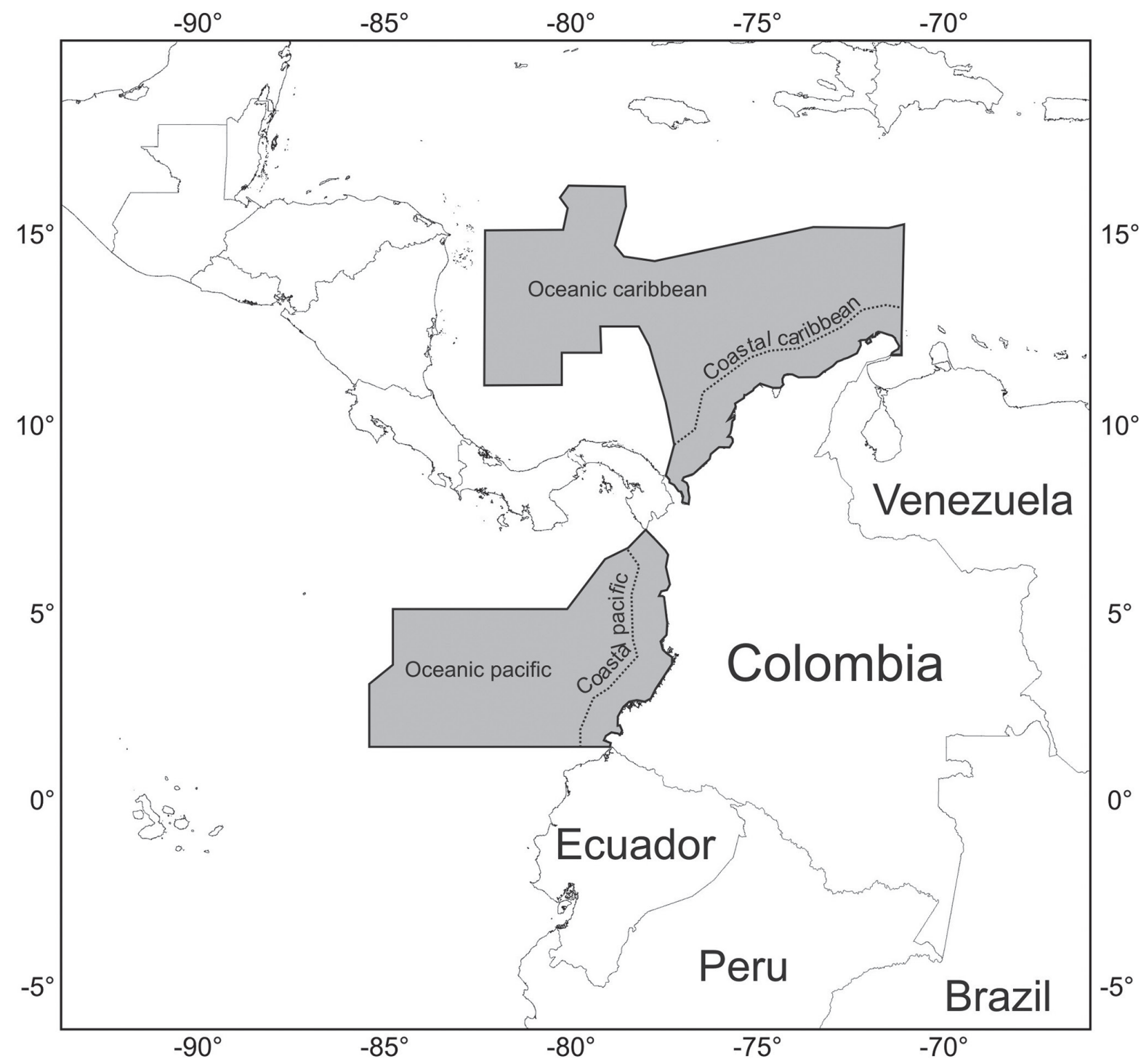

Fig. 1. Study area indicating the territorial limits of the Colombian seas. The dotted lines indicate the partitioning into the subareas (Coastal Caribbean, Oceanic Caribbean, Coastal Pacific and Oceanic Pacific) used in this study. 
Data Analysis. Information on species richness for each group (sharks and batoids) in each area (Pacific and Caribbean) was plotted comparatively to assess both the overall (both areas) and relative (to each area) contribution of each family to the richness and distribution patterns of elasmobranch in Colombian seas. The overall contribution was measured as the number of species of a given family over the total number of recorded species in both areas, while the relative contribution was measured as the number of species of a given family over the total number of species in the area being evaluated. A similarity analysis at the family level was performed using Morisita's similarity index (since it is independent of the sample size), and the UPGMA clustering algorithm (Unweighted Pair Group Method with Arithmetic mean; Krebs, 1999). Furthermore the bootstrap (1000 replicates) value of each group was reported. This analysis was performed in PAST software (Hammer et al., 2001). The shared and exclusive species as well as the genera richness in each area were also evaluated. Likewise, the richness by occupied habitat (coastal, coastal-oceanic, oceanic and deep water), and the habits of the species (bentopelagic, benthic and pelagic) were also evaluated. The classifications were determined following the criteria of Musick et al. (2004).

The richness of sharks and batoids by size interval $(<100$ $\mathrm{cm}, 100$ to $200 \mathrm{~cm}, 200$ to $300 \mathrm{~cm}$ and $>300 \mathrm{~cm}$ of total length (TL)) were estimated, and the relationship between the maximum length of each species (recorded in Colombia) and the number of occupied subareas was evaluated using a linear regression.

Elasmobranch species turnover (beta diversity) among coastal and oceanic environments of the Caribbean and Pacific areas was determined using the similarity index of Cody ( $\beta$ ), which measures the species replacement among sampling units (subareas), and is expressed as:

$$
\beta=1-\frac{c(a+b)}{2 a b}
$$

where $a$ is the species number present in subarea $\mathrm{A}, b$ is the species number present in subarea $\mathrm{B}$, and $c$ is the species number present in both A and B.

To evaluate the effect of species vagility on the observed distribution patterns, the permeability to geographical barriers was calculated as the specific covariance of occurrences (Smith \& Bermingham, 2005). This value expresses the replacement rate among studied environments, and is estimated for area pairs (or subareas in this study), following the equation:

$$
\operatorname{Cov}\left(x_{i j} x_{i k}\right)=\frac{\left(n_{11} n_{00}-n_{10} n_{01}\right)}{N(N-1)}
$$

where $n_{11}$ is the number of species found in both subareas, $n_{10}$ is the number of species found in the subarea $j$ but not in $k, n_{01}$ is the number of species found in subarea $k$ but not in $j$, $n_{00}$ is the number of species not found in any of the subareas, and $N$ is the total number of species studied. Higher values of co-variation between two geographical areas (or subareas) indicate greater faunal similarity and therefore, higher permeability to each other. It is also an indicator of a decrease in beta diversity or species turnover between the compared areas (or subareas). A presence-absence matrix in the four sub-areas was used following Smith \& Bermingham (2005).

Rajidae is one of the groups with the highest zoogeographic complexity in Colombia, making it difficult to test any distributional hypothesis. For this reason, a phylogeographic method was used to test the hypothesis of the affinity of Rajidae to any given region. A phylogenetic tree mapped into a world map was rendered. For this, the sequence and geographic information was downloaded from BOLD systems public records database (Ratnasingham \& Hebert, 2007) (S1 - Available only as online supplementary file accessed with the online version of the article at http://www. scielo.br/ni). The data was filtered to gather only sequences with geographical information. BOLD systems contain only cytochrome oxidase subunit 1 DNA sequences. Once the sequences and metadata were obtained, a codon-based alignment and curation were performed using TranslatorX (Abascal et al., 2010), with default settings. The translation was performed using the Vertebrate Mitochondrial genetic code. Extensive (more than $90 \%$ of the sequences) gapped regions at the beginning and end of the alignment were manually removed. A total of 350 sequences 630 base-pairs long were gathered (S2 - Available only as online supplementary file accessed with the online version of the article at http:// www.scielo.br/ni). The phylogenetic tree was inferred using the Maximum Likelihood (ML) under the General Time Reversible model (Nei \& Kumar, 2000). The tree with the highest log likelihood (-6243.8932) was retained. The initial tree for the heuristic search was obtained through Maximum Parsimony. A discrete Gamma distribution was used to model the evolutionary rate differences among sites (4 categories, parameter $=0.4133$ ). The rate variation model allowed for some sites to be evolutionarily invariable. The tree is drawn to scale, with branch lengths measured in the number of substitutions per site. All positions with less than $95 \%$ site coverage were eliminated. That is, fewer than 5\% alignment gaps, missing data, and ambiguous bases were allowed at any position. A bootstrap analysis with 500 replicates was performed, and the consensus tree rendered. Evolutionary analyses were conducted in MEGA6 (Tamura et al., 2013).

The mapping of the consensus ML tree was performed using GenGIS (Parks et al., 2009). The height of the tree overlay corresponds to branch lengths.

\section{Results}

Elasmobranch richness by families (Caribbean and Pacific areas). There are 117 (64 sharks and 53 batoids) confirmed marine elasmobranch species in Colombian waters. These species are grouped into 26 families (16 sharks and 10 batoids). From those, 62 inhabit the Pacific Ocean while 75 inhabit the Caribbean Sea. 
Ten shark families are shared between the areas, two are exclusively Pacific (Odontaspididae and Heterondontidae) and four are exclusively Caribbean (Squalidae, Centrophoridae, Mitsukirinidae and Scyliorhinidae) (Fig. 2). Carcharhinidae is the family that contributed the most to shark diversity in Colombia (15.38\%), followed by Scyliorhinidae, Etmopteridae and Triakidae (5.98\% each) (Fig. 2). Likewise, the relative contribution per family for the Pacific was dominated by Carcharhinidae (21\%) followed by Sphyrnidae (8.1\%). The Caribbean showed Carcharhinidae (17.33\%) followed by Scyliorhynidae (9.33\%) and Etmopteridae (8\%) as the dominant families (Fig. 2).

Nine batoid families were shared between the areas. Anacanthobatidae is unique to the Caribbean, represented by two genera and two species (Fig. 2). Rajidae (8.55\%), Myliobatidae and Urotrygonidae $(6.84 \%$ each) were the families that contributed the most to the batoid richness, the former being the most representative for the Caribbean and the latter for the Pacific. These families were followed by Myliobatidae (6.67\%), Narcinidae and Dasyatidae (4\% each) in the Caribbean, and by Myliobatidae (8.1\%), Rhinobatidae and Narcinidae in the Pacific $(6.5 \%$ each) (Fig. 2).

Five major groups of elasmobranch families inhabiting the Colombian areas were identified with the similarity analysis (Fig. 3). Association A1 (Odontaspididae and Heterodontidae) corresponds to exclusively Pacific species, while the species in group $\mathrm{C} 1$ are exclusive to the Caribbean. A2 group is not exclusive to Pacific but its families have more species in this area. Similarly, the families in $\mathrm{C} 2$ group have more species in the Caribbean. By contrast, families in group B did not provide meaningful information to establish differences in richness of the elasmobranch fauna between those two areas.

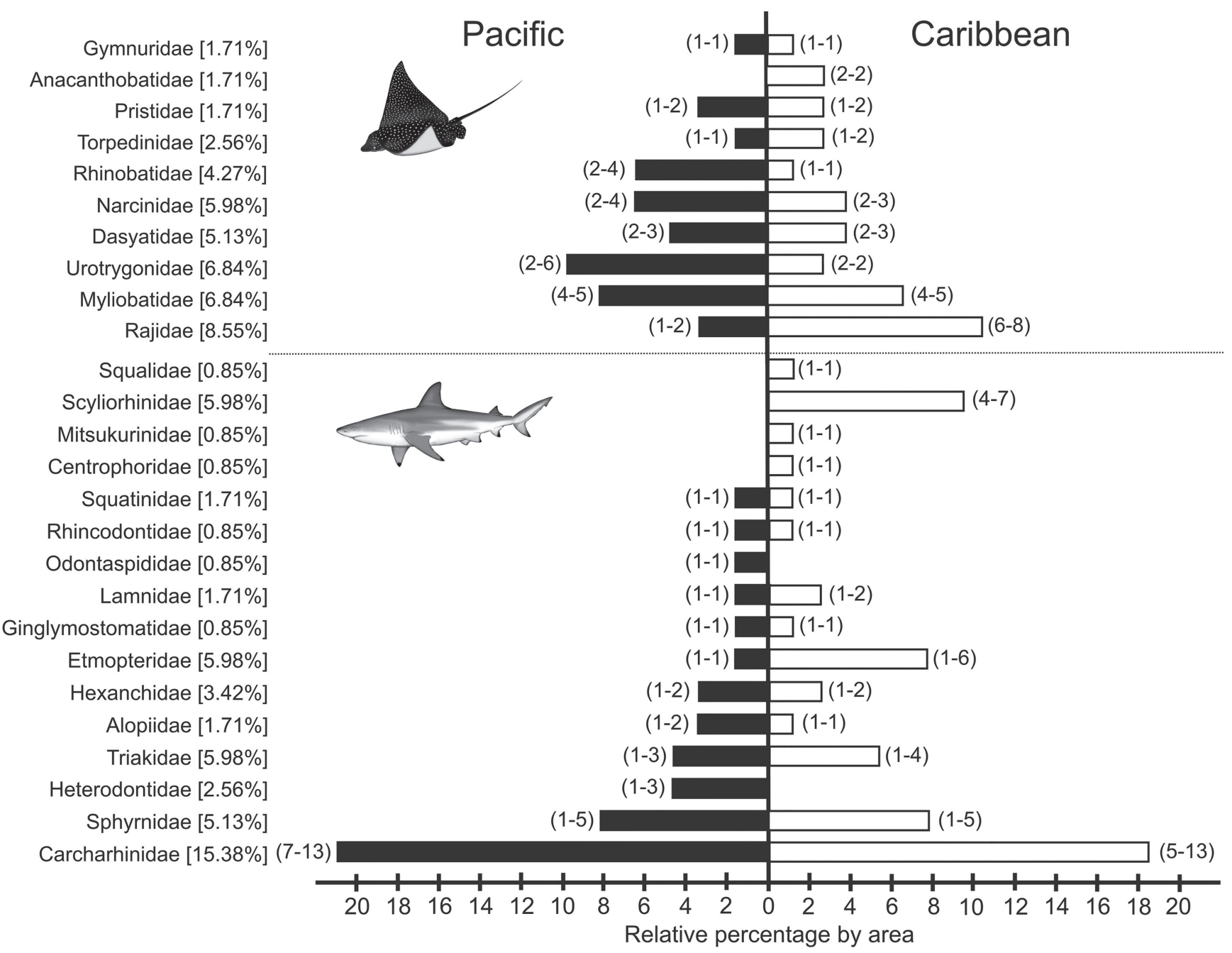

Fig. 2. Relative contribution of each family to the total richness of elasmobranchs for both areas combined (values in brackets) and by area, Colombian Pacific (black bars) and Caribbean (white bars). Values in parentheses indicate the total number of genera (first entry) and species (second entry) per family. 


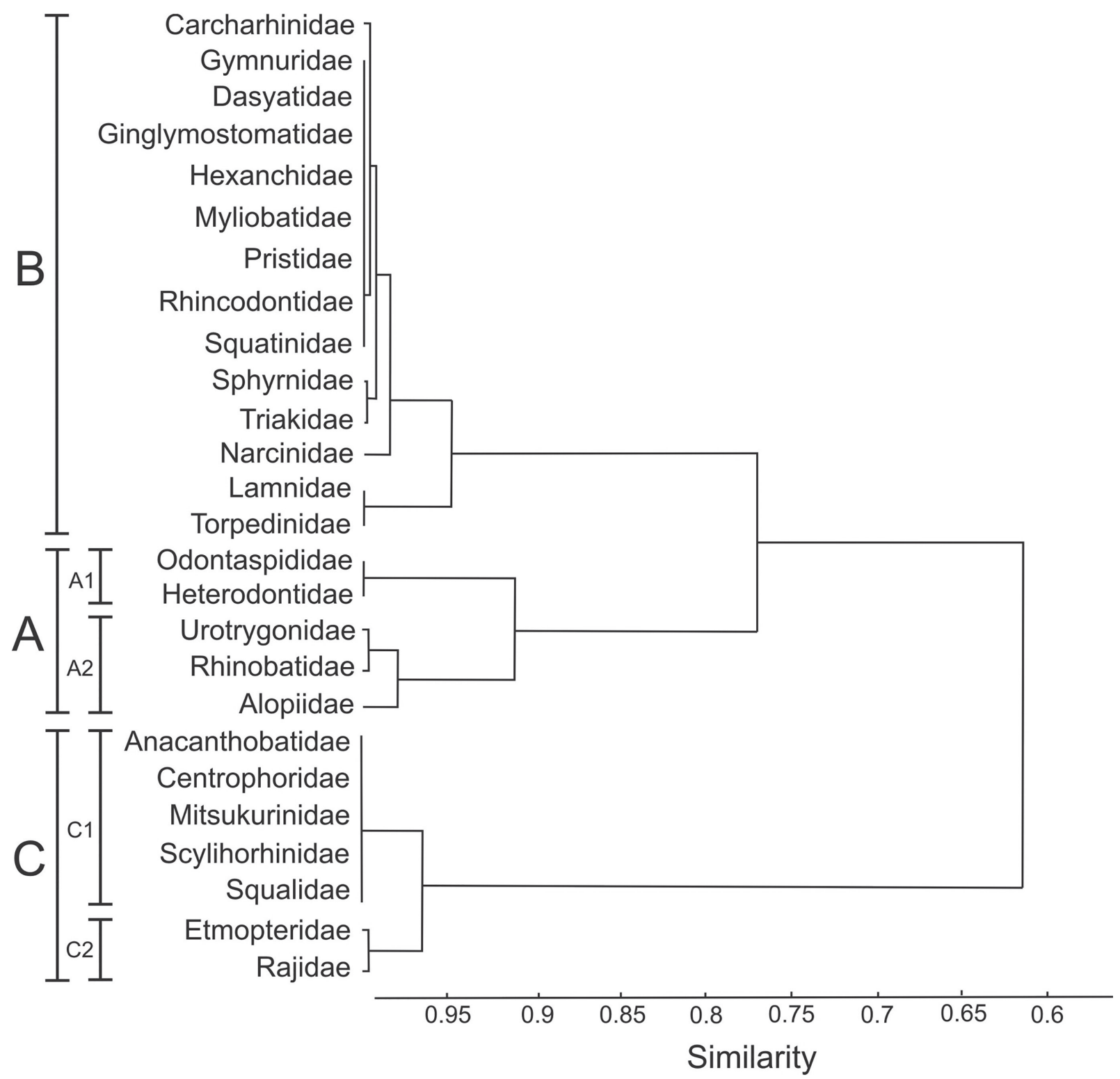

Fig. 3. Similarity analysis of elasmobranch families per number of species present in the Colombian Caribbean and Pacific. A: Pacific-associated; B: Associated with both areas, Caribbean and Pacific; C: Caribbean-Associated. The subgroups in $\mathrm{A}(\mathrm{A} 1, \mathrm{~A} 2)$ and $\mathrm{C}(\mathrm{C} 1, \mathrm{C} 2)$ correspond to families exclusive to the area or shared but predominant in the area, respectively.

Elasmobranch richness by genera and species. The Caribbean and Pacific share 16 shark species, with Carcharhinus and Sphyrna being the major contributors to this similarity. However, the Caribbean has greater shark richness than the Pacific (46 and 34 species, respectively) (Table 1). By contrast, there are only four shared batoid species between those areas and the contribution of each area to richness is more homogeneous (28 and 29) (Table 1).

Considering the four subareas, coastal Caribbean had the highest number of shark species followed by coastal Pacific and oceanic Caribbean. For batoids, coastal Pacific and coastal Caribbean had the highest number of species, while the two oceanic environments exhibited low diversity (Table 1).
Elasmobranch richness vs. habitats, habits, and body size of the species. Most of the Colombian tropical marine elasmobranchs are benthic (47 are benthic and 57 are bentopelagic). Pelagic groups are less diverse (Fig. 4a). The majority of species (67) are associated with coastal habitats (27 sharks and 40 batoids) followed by deep water for the Caribbean (26) and by coastal-oceanic for the Pacific (16). In both areas, oceanic species were considerably less represented (Fig. 4b).

Most batoid species (63.52\%) have sizes under $100 \mathrm{~cm}$ (TL) while $60.9 \%$ of shark species have sizes under 200 $\mathrm{cm}$ TL. However, the presence of shark species larger than $300 \mathrm{~cm}$ TL is considerable (34.41\%) (Fig. 4c). Likewise, a positive relationship between body size and number of occupied subareas was found $\left(\mathrm{r}^{2}=0.47 ; \mathrm{P}<0.05\right.$; Fig. $\left.4 \mathrm{~d}\right)$. 
Table 1. Richness of genera and species of sharks and batoids in the Colombian Caribbean and Pacific.

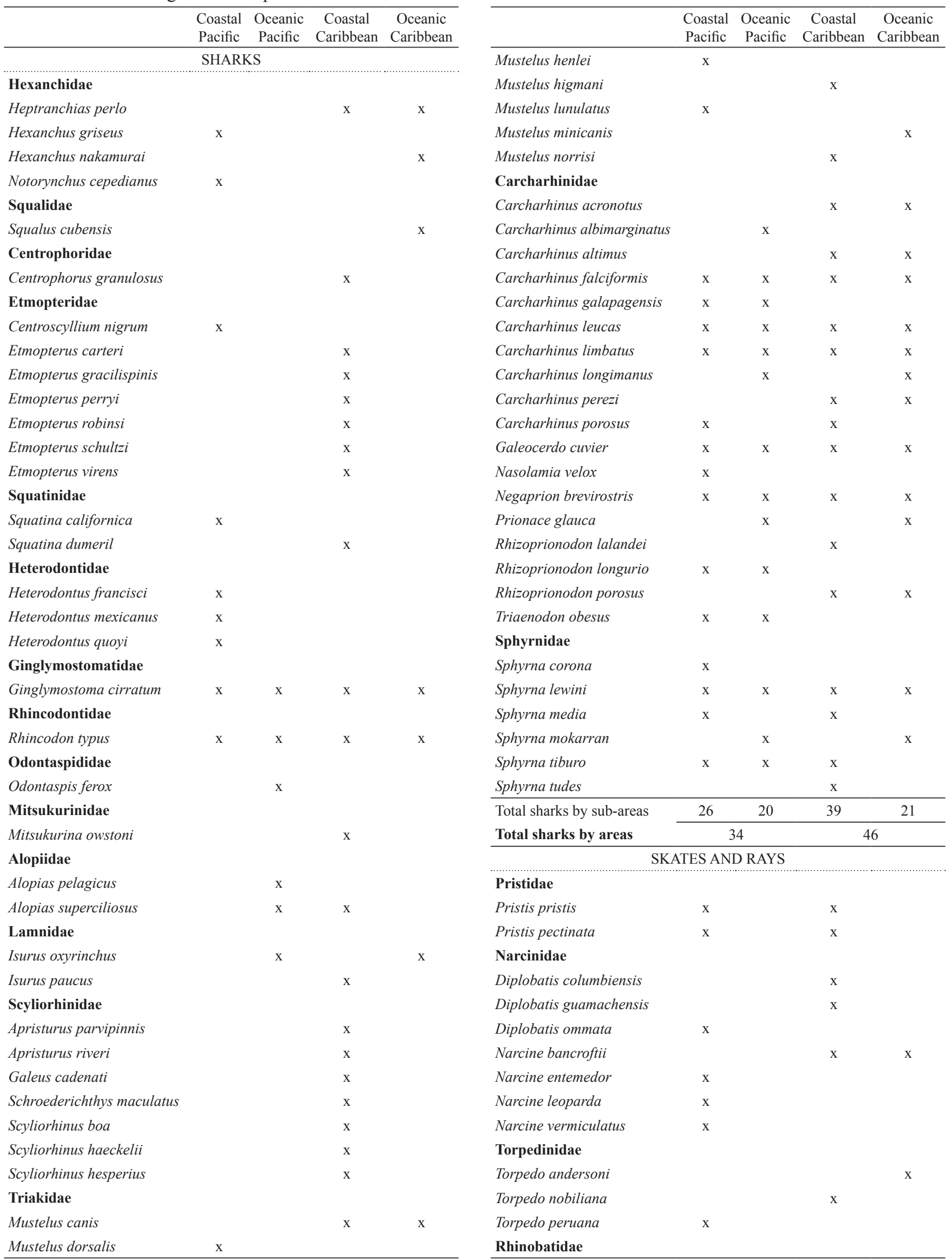


Table 1. (conclusion).

\begin{tabular}{|c|c|c|c|c|}
\hline & $\begin{array}{l}\text { Coastal } \\
\text { Pacific }\end{array}$ & $\begin{array}{c}\text { Oceanic } \\
\text { Pacific }\end{array}$ & $\begin{array}{c}\text { Coastal } \\
\text { Caribbean }\end{array}$ & $\begin{array}{c}\text { Oceanic } \\
\text { Caribbean }\end{array}$ \\
\hline Rhinobatos leucorhynchus & $\mathrm{x}$ & & & \\
\hline Rhinobatos percellens & & & $\mathrm{x}$ & $\mathrm{x}$ \\
\hline Rhinobatos planiceps & $\mathrm{x}$ & & & \\
\hline Rhinobatos prahli & $\mathrm{x}$ & & & \\
\hline Zapteryx xyster & $\mathrm{x}$ & & & \\
\hline \multicolumn{5}{|l|}{ Rajidae } \\
\hline Breviraja nigriventralis & & & $\mathrm{x}$ & \\
\hline Dactylobatis clarkii & & & $\mathrm{x}$ & \\
\hline Dipturus bullisi & & & $\mathrm{x}$ & \\
\hline Dipturus garricki & & & $\mathrm{x}$ & \\
\hline Dipturus teevani & & & $\mathrm{x}$ & \\
\hline Gurgesiella atlantica & & & $\mathrm{x}$ & \\
\hline Raja cervigoni & & & $\mathrm{x}$ & \\
\hline Raja equatorialis & $\mathrm{x}$ & & & \\
\hline Raja velezi & $\mathrm{x}$ & & & \\
\hline Rajella purpuriventralis & & & $\mathrm{x}$ & \\
\hline \multicolumn{5}{|l|}{ Anacanthobatidae } \\
\hline Anacanthobatis americanus & & & $\mathrm{x}$ & \\
\hline Cruriraja rugosa & & & $\mathrm{x}$ & \\
\hline \multicolumn{5}{|l|}{ Urotrygonidae } \\
\hline Urobatis tumbesensis & $\mathrm{x}$ & & & \\
\hline Urobatis halleri & $\mathrm{x}$ & $\mathrm{x}$ & & \\
\hline Urobatis jamaicensis & & & $\mathrm{x}$ & $\mathrm{x}$ \\
\hline Urotrygon aspidura & $\mathrm{x}$ & & & \\
\hline Urotrygon chilensis & $\mathrm{x}$ & & & \\
\hline Urotrygon munda & $\mathrm{x}$ & & & \\
\hline Urotrygon rogersi & $\mathrm{x}$ & & & \\
\hline Urotrygon venezuelae & & & $\mathrm{x}$ & \\
\hline \multicolumn{5}{|l|}{ Dasyatidae } \\
\hline Dasyatis americana & & & $\mathrm{x}$ & $\mathrm{x}$ \\
\hline Dasyatis dipterura & $\mathrm{x}$ & & & \\
\hline Dasyatis guttata & & & $\mathrm{x}$ & \\
\hline Dasyatis longa & $\mathrm{x}$ & & & \\
\hline Himantura pacifica & $\mathrm{x}$ & $\mathrm{x}$ & & \\
\hline Himantura schmardae & & & $\mathrm{x}$ & \\
\hline \multicolumn{5}{|l|}{ Gymnuridae } \\
\hline Gymnura marmorata & $\mathrm{x}$ & & & \\
\hline Gymnura micrura & & & $\mathrm{x}$ & \\
\hline \multicolumn{5}{|l|}{ Myliobatidae } \\
\hline Aetobatus narinari & $\mathrm{x}$ & $\mathrm{x}$ & $\mathrm{x}$ & $\mathrm{x}$ \\
\hline Manta birostris & $\mathrm{x}$ & $\mathrm{x}$ & $\mathrm{x}$ & $\mathrm{x}$ \\
\hline Mobula hypostoma & & & & $\mathrm{x}$ \\
\hline Mobula munkiana & $\mathrm{x}$ & $\mathrm{x}$ & & \\
\hline Mobula thurstoni & $\mathrm{x}$ & $\mathrm{x}$ & & \\
\hline Rhinoptera bonasus & & & $\mathrm{x}$ & \\
\hline Rhinoptera brasiliensis & & & $\mathrm{x}$ & \\
\hline Rhinoptera steindachneri & $\mathrm{x}$ & $\mathrm{x}$ & & \\
\hline Total skates and rays by sub-areas & 28 & 7 & 27 & 8 \\
\hline Total skates and rays by areas & & 28 & 2 & \\
\hline
\end{tabular}
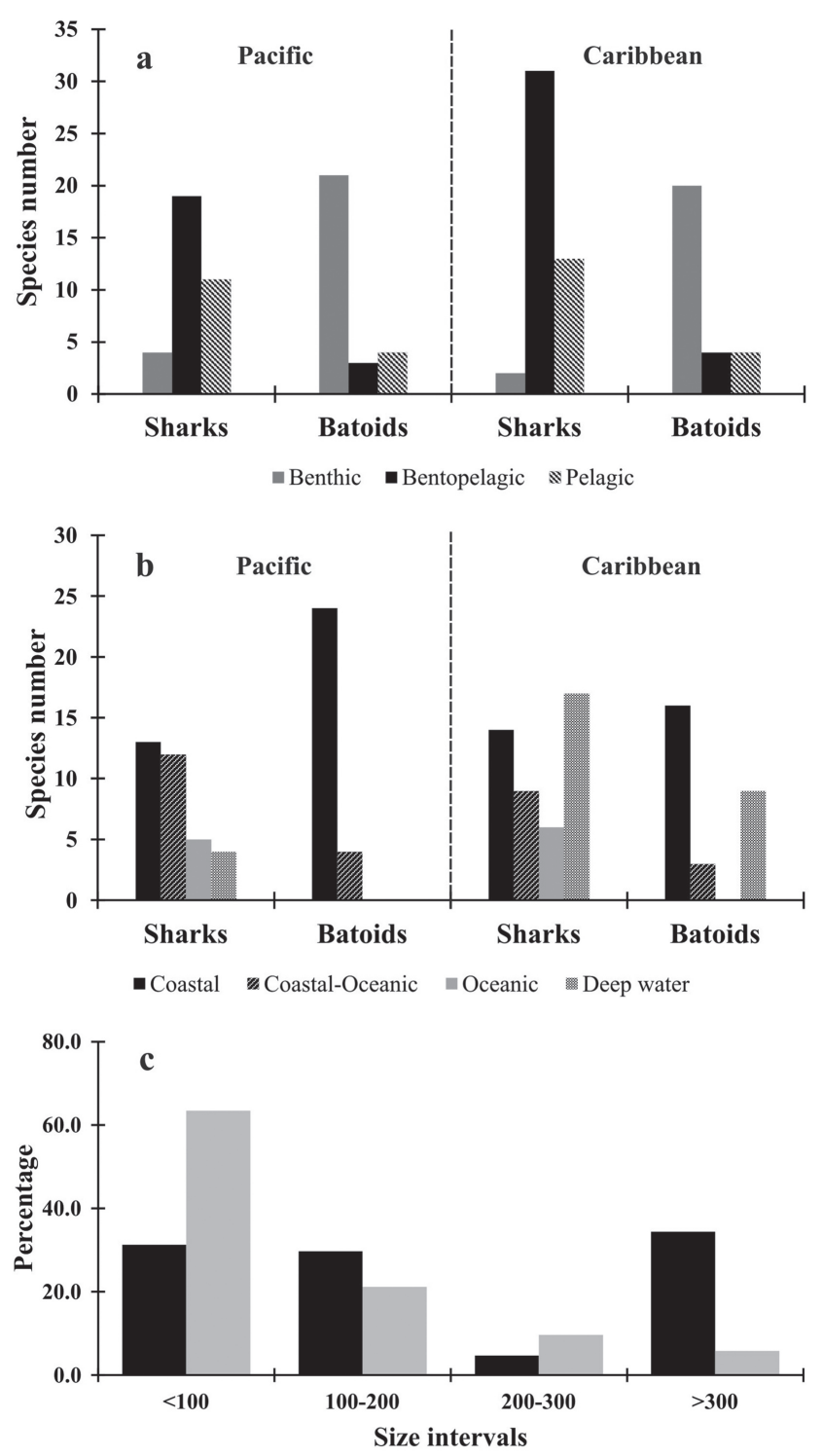

- Sharks $m$ Batoids

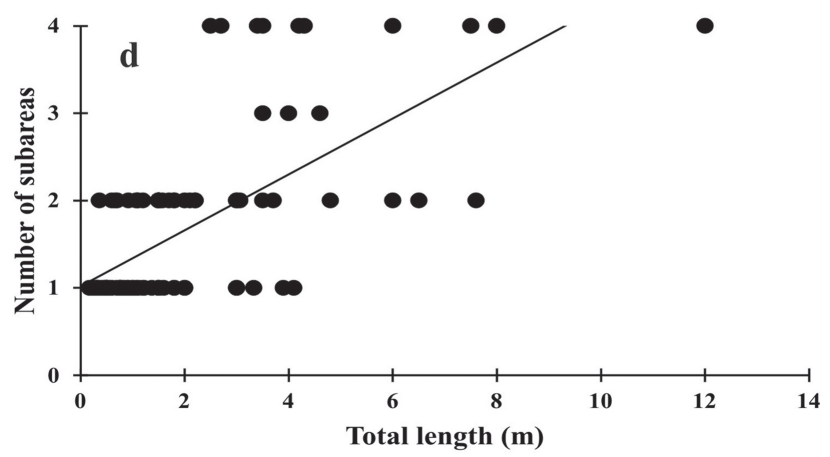

Fig. 4. Shark and batoid richness per habitat (a) and per habit (b) in the Colombian Pacific and Caribbean waters, and relationship between the body size of Colombian marine elasmobranchs and its richness (c; values expressed in percentage) and the number of sub-areas (Oceanic Caribbean, Coastal Caribbean, Oceanic Pacific, and Coastal Pacific) occupied by them (d). 
Beta diversity (subareas). Most elasmobranch species turnover occurs between the subareas Coastal Pacific and Oceanic and Coastal Caribbean (Table 2). Similar results were found for sharks and batoids separately, with the highest turnover found between Coastal Pacific and Oceanic Caribbean and between Coastal Pacific and Coastal Caribbean, respectively. For both groups, the lowest turnover was between Coastal Pacific and Oceanic Pacific (Table 2).

Species vagility among subareas. In the joint analysis (elasmobranch as a single group) the Coastal and Oceanic Pacific subareas had the greatest faunal similarity. In contrast, Coastal Pacific and Coastal Caribbean showed the lowest similarity (Table 2). Similarly, shark and batoid analyses exhibited the same pattern with Coastal Pacific and Oceanic Pacific having the highest similarity values and Coastal Pacific and Coastal Caribbean with the lowest similarity between subareas (Table 2). The highest covariance value (greater vagility) was recorded for sharks, while the lowest value (lower vagility) was found for batoids (Table 2).

Our results show that the South American Rajidae assemblage is closer to the Austral regions than the Atlantic region (S3 - Available only as online supplementary file accessed with the online version of the article at http:// www.scielo.br/ni), supporting a closer origin of these two groups. It also shows the high diversity of Rajidae in the Mediterranean with deeper relationships (more ancient divergence) when compared to the rest of the world.

Table 2. Beta diversity values $(\beta)$ and occurrence specific covariance (Cov) of shark and batoid species among the four tropical marine sub-areas of the Colombian Caribbean and Pacific.

\begin{tabular}{lcccccc}
\hline \multirow{2}{*}{ Sub-areas } & \multicolumn{2}{c}{ Elasmobranchs (joint analysis) } & \multicolumn{2}{c}{ Sharks } & \multicolumn{2}{c}{ Batoids } \\
\cline { 2 - 7 } & Beta & Cov & Beta & Cov & 0.109 & 0.357 \\
\hline Coastal Pacific and Oceanic Pacific & 0.390 & 0.084 & 0.333 & 0.072 & -0.196 \\
Coastal Pacific and Coastal Caribbean & 0.744 & -0.129 & 0.644 & -0.070 & 0.852 & -0.821 \\
Coastal Pacific and Oceanic Caribbean & 0.756 & -0.047 & 0.692 & -0.041 & -0.035 \\
Oceanic Pacific and Oceanic Caribbean & 0.701 & -0.045 & 0.635 & -0.061 & 0.837 & -0.039 \\
Oceanic Pacific and Coastal Caribbean & 0.545 & 0.049 & 0.490 & 0.045 & 0.732 \\
Coastal Caribbean and Oceanic Caribbean & 0.495 & 0.039 & 0.449 & 0.036 & 0.547 & 0.018 \\
\hline
\end{tabular}

\section{Discussion}

The elasmobranch fauna of Colombia is richer in comparison with other Neotropical countries such as Ecuador (Jiménez-Prado \& Béarez, 2004), Venezuela (Cervigón \& Alcalá, 1999) and Costa Rica (Bussing \& López, 1993, 2010). Even compared to countries with two coast lines like Mexico, whose coastline is three times longer than Colombia's (Del Moral Flores \& Pérez Ponce de León, 2013), elasmobranch richness of Colombia remains high. It includes $52 \%$ of families, $29.14 \%$ of genera and $10.40 \%$ of species of marine elasmobranchs of the world. Additionally, our results placed the Colombian elasmobranch fauna within the biogeographic regions of the Tropical Eastern Pacific - TEP- and the Western Central Atlantic - WCA.

Only one endemic species was recorded in Colombian waters, Diplobatis columbiensis in the Caribbean Sea. This number of endemic species is particularly low if compared to the Australia biogeographic region (Last \& Yearsley, 2002; Last \& White, 2011).

Elasmobranch richness in the Caribbean and Pacific. Distribution of genera and species richness in the Pacific (35 and 63 , respectively) and Caribbean (43 and 74, respectively) are consistent with the pattern observed in fishes, with $20 \%$ less richness in the Eastern Tropical Pacific (TEP) than in its sister region, the Great Caribbean (Robertson \& Allen, 2008; Carpenter, 2002). Robertson \& Allen (2008) outline as the first cause of this pattern the relatively simple geography and the small quantity of coastal habitats (mainly continental) in the TEP while the Caribbean is more geographically complex and comparatively has a wider continental shelf and more oceanic islands.

Another possible cause of lower elasmobranch species richness in the Pacific compared with other regions of the world (Last \& White, 2011) is that smaller benthic sharks (such as the Orectolobiformes), that contribute substantially to Indo-Pacific diversity, have not been able to reach the Pacific oceanic islands (Springer, 1982).The strength of this East Pacific Barrier in elasmobranch dispersion has been observed in the species richness of Australasia (Last \& Yearsley, 2002) and the TEP, where even highly vagile species such as Manta birostris have restricted gene flow between these areas (Clark, 2002), and only very few shark species (e.g. Carcharhinus albimarginatus, C. galapagensis, Triaenodon obesus) have an amphi-Pacific distribution (Robertson \& Allen, 2008).

Likewise, the total absence of the Squaliform and most Rajiform families in the eastern Pacific coast substantially reduces the species richness in the study area when compared with other geographical areas. For example in Australia and the Indo-Pacific the elasmobranch species richness and endemism are concentrated in Rajiformes and Squaliformes, which represent more than half of the extant elasmobranchs (Compagno, 2005).

The biogeographical origin of elasmobranchs in the Neotropics could be explained by three hypotheses. First, the Tethyan hypothesis (Schultz et al., 2008), mainly applying 
to groups with genera origins dating to more than 50 mya, and with low vagility representatives in both western Atlantic and American coasts. The Tethyan hypothesis posits that the range of coastal species was sundered by closure of the Tethys Sea, linking the Indian and Atlantic Ocean coasts and isolating American and western Atlantic species. Subsequently, the emergence of the Panama Isthmus isolated the American Atlantic and the American Pacific (Musick et al., 2004; Schultz et al., 2008). Second, local speciation (Lim et al., 2010; Stelbrink et al., 2010), where amphi-American genera with species endemic to the neotropics (e.g. Sphyrna tudes vs. Sphyrna media, Squatina dumeril vs. Squatina californica) follow a geminate species pattern likely split by the Isthmus of Panama.

Third, and specific to Rajidae, is Austral origin. This observation is supported by Last \& Yearsley (2002), who stated that some of the Rajidae subfamilies existed in Gondwana before its fragmentation, giving to the austral region both palaeo-Austral and Tethyan remnants, and therefore a greater diversity. The authors also point out that the occurrence of Zearaja species in austral regions and South America, supports the claim of Gondwanan speciation before the separation and isolation of Australian and South American fragments about 50 mya (Pielou, 1979; Hallam, 1981; Pitman III et al., 1993). However, the scant presence of the species in the Atlantic and Indian Oceans suggests that a Tethyan link is unlikely (Last \& Yearsley, 2002) and therefore, Rajidae representation in Colombian waters is more likely due to dispersal from southern South America.

Elasmobranch richness vs. habitats, habits, and body size. Habits of elasmobranch species influence their distribution. Most of the pelagic species were present in all four sub-areas, whereas benthic species were restricted to one or at most two subareas. The majority of the species that were associated to coastal habitats are small and/ or less vagile. Therefore, distribution patterns of tropical elasmobranch species of Colombia are strongly related with their size, an observation common to other areas (Musick et al., 2004).

Beta diversity (subareas). The observed differences between the elasmobranch faunas of coastal Pacific and coastal Caribbean might be influenced by the presence of numerous genera and species of restricted mobility (benthic sharks, skates and rays). Such species have been more affected by vicariant events such as the closure of the Isthmus of Panama and could favor differential speciation or extinction (Robertson \& Allen, 2008).

This is reflected by the observation of shared genera with different numbers of species (Diplobatis, Urobatis, Urotrygon, and Rhinobatos), and by genera that only exist in the Caribbean (Anacanthobatis, Breviraja, among others). Likewise, Etmopteridae, Scyliorhindae, Narcinidae and Rhinobatidae have different genera and species numbers in the Pacific and the Caribbean that could reflect speciation by vicariance and extinction. Etmopteridae seems to have an Atlantic origin, since its diversity is higher there (Musick et al., 2004). Narcinidae have higher homogeneity in species number between areas (3 in Caribbean, 4 in Pacific), being Diplobatis the main component in the Caribbean and Narcine in the Pacific. Urotrygonidae has two genera and 17 amphiamerican species while its sister group, Urolophidae, is endemic to the west Pacific showing three genera and 22 species (Nelson, 2006).

According to Robertson \& Allen (2008) the fish fauna of the Tropical Eastern Pacific has a strong relationship with the coastal fishes of the Greater Caribbean and a significant endemism at the species level. Our results showed higher endemism in the Caribbean, which conforms to the fact that the Colombian Caribbean coast is part of the second zone with more richness and endemism of the Western Central Atlantic (Carpenter, 2002).

Species vagility among subareas. The biggest similarity found between Coastal Pacific and Oceanic Pacific subareas can be explained by their geographical proximity and the presence of a large number of species with high vagility (e.g. Carcharhinus spp., Sphyrna spp., Mustelus spp., Mobula ssp. and Rhincodon typus, Manta birostris and Aetobatus narinari). This capacity to overcome aquatic barriers has been recorded before (Castro-Aguirre, 1983; Díaz, 1984; Bonfil et al., 2005; Gore et al., 2008; Sequeira et al., 2013). The higher isolation between the two coastal areas (Caribbean and Pacific) in batoids is because its species richness is dominated by species with smaller size $(<100 \mathrm{~cm})$, of benthic habits, and restricted to coastal environments.

Colombian elasmobranch have multiple origins. Local diversification/speciation, dispersal from the non-tropical regions of the Americas, and Pacific and Atlantic dispersal are all possibilities for origin without any of them excluding the others. A more exhaustive phylogenetic survey including molecular clocks with more points of calibration is required. This is an especially difficult task since the elasmobranch fossil record is scant, and the age of the fossils that exist cannot be accurately determined as the first appearance of the species.

\section{Acknowledgements}

The authors thank G. Dean for the review of the English version of this manuscript. K. Narvaez and two anonymous reviewers whose comments allowed us to improve the quality of this paper.

\section{References}

Abascal, F., R. Zardoya \& M. J. Telford. 2010. TranslatorX: multiple alignment of nucleotide sequences guided by amino acid translations. Nucleic Acids Research, 38: w7-w13. 
Acevedo, K., J. Bohórquez-Herrera, F. Moreno, C. Moreno, E. Molina, L. M. Grijalba-Bendeck \& P. Gómez-Canchong. 2007. Tiburones y rayas (Subclase Elasmobranchii) descartados por la flota de arrastre camaronero en el Caribe de Colombia. Acta Biológica Colombiana, 12: 69-80.

Anderson, S. 1994. Area and endemism. The Quarterly Review of Biology, 69: 451-471.

Bonfil, R., M. Meyer, M. C. Scholl, R. Johnson, S. O’Brien, H. Oosthuizen, S. Swanson, D. Kotze \& M. Paterson. 2005. Transoceanic migration, spatial dynamics, and population linkages of white sharks. Science, 310: 100-103.

Bush, G. L. 1975. Modes of animal speciation. Annual Review of Ecology and Systematics, 6: 339-364.

Bussing, W. A. \& M. López S. 1993. Peces demersales y pelágicos costeros del Pacífico de Centro América meridional. Guía ilustrada. Publicación especial de la Revista de Biología Tropical, 164p.

Bussing, W. A. \& M. López. 2010. Peces costeros del caribe de Centro América meridional. Guía ilustrada. Revista de Biología Tropical, 57: 1-240.

Cappetta, H. 1987. Chondrichthyes II: Mesozoic and Cenozoic Elasmobranchii. V. 3B: Pp. 1-193. In: Schultze, H. -P. (Ed.). Handbook of Paleoichthyology. Stuttgart; New York, Fischer Verlag.

Carpenter, K. E. (Ed.). 2002. The living marine resources of the Western Central Atlantic. FAO species identification guide for fisheriey purposes. Roma, FAO, V 1: Introduction, molluscs, crustaceans, hagfishes, sharks, batoid fishes and chimaeras (Species Identification Guide for Fishery Purposes and American Society of Ichthyologists and Herpetologists Special Publication, no. 5).

Castro-Aguirre, J. L. 1983. Aspectos zoogeográficos de los elasmobranquios mexicanos. Anales de la Escuela Nacional de Ciencias Biológicas, México, 27: 77-94.

Cervigón, F. \& A. Alcalá. 1999. Los peces marinos de Venezuela, 2 ed. Caracas, Fundación Museo del Mar, V. 5.

Clark, T. B. 2002. Population structure of Manta birostris (Chondrichthyes: Mobulidae) from the Pacific and Atlantic Oceans. Unpublished M.Sc. Thesis, Texas A \& M University, Texas, 67 p. available from: http://hdl.handle.net/1969.1/ETDTAMU-2002-THESIS-C454

Compagno, L. J. V. 2005. Check list of living elasmobranchs. Pp. 503-548. In: Hamlett, W. C. (Ed.). Reproductive biology and phylogeny of Chondrichthyes: sharks, batoids and chimaeras. Enfield, NH, Science Publishers.

Del Moral Flores, L. F. \& G. Pérez Ponce de León. 2013. Tiburones, rayas y quimeras de México. Biodiversitas, 111: 1-6.

Díaz, J. M. 1984. Consideraciones zoogeograficas sobre los tiburones del Pacífico colombiano. Anales del Instituto de Investigaciones Marinas, Punta de Betín, 13: 53-65.

Dulvy, N. K, S. L. Fowler, J. A. Musick, R. D. Cavanagh, P. M. Kyne, L. R. Harrison, J. K. Carlson, L. N. K. Davidson, S. V. Fordham, M. P. Francis, C. M. Pollock, C. A. Simpfendorfer, G. H. Burgess, K. E. Carpenter, L. J. V. Compagno, D. A. Ebert, C. Gibson, M. R. Heupel, S. R Livingstone, J. C Sanciangco, J. D. Stevens, S. Valenti \& W. T White. 2014. Extinction risk and conservation of the world's sharks and rays. eLife, 3: e00590.
Gore, M. A., D. Rowat, J. Hall, F. R. Gell \& R. F. Ormond. 2008. Transatlantic migration and deep mid-ocean diving by basking shark. Biology Letters, 4: 395-398.

Grijalba-Bendeck, M., C. Polo-Silva \& A. Acero P. 2007. Una aproximación a la abundancia de los Batoideos capturados artesanalmente en Santa Marta (Colombia). Boletín de Investigaciones Marinas y Costeras, 36: 251-268.

Grijalba-Bendeck, M., C. Polo-Silva, K. Acevedo, F. Moreno \& D. Mojica. 2012. Aspectos tróficos y reproductivos de algunos batoideos capturados en Santa Marta, Mar Caribe de Colombia. Latin American Journal of Aquatic Research, 40: 300-315.

Hallam, A. 1981. Relative importance of plate movements, eustasy and climate in controlling major biogeographical changes since the early Mesozoic. Pp. 303-330. In: Nelson, G. \& D. E. Rosen (Eds.). Vicariance biogeography: a critique: Symposium of the systematic discussion group of the American Museum of Natural History, May 2-4, 1979.

Hammer, Ø., D. A. T. Harper \& P. D. Ryan. 2001. PAST: Paleontological Statistics Software Package for Education and Data Analysis. Palaeontologia Electronica, 4: 1-9.

Hleap, J. S., P. A. Mejía-Falla \& H. Cárdenas. 2012. Relaciones morfométricas de la raya redonda Urotrygon rogersi: implicaciones cuantitativas bajo modelos lineales. Revista de Biología Marina y Oceanografía, 47: 35-50.

Hrabik, T. R., B. K. Greenfield, D. B. Lewis, A. I. Pollard, K. A. Wilson \& T. K. Kratz. 2005. Landscape-scale variation in taxonomic diversity in four groups of aquatic organisms: the influence of physical, chemical, and biological properties. Ecosystems, 8: 301-317.

Ishihara, H. 1991. Biogeography of skates of the family Rajidae. Aquabiology, 13: 280-286.

Jiménez Prado, P. \& P. Béarez. 2004. Peces marinos del Ecuador continental. Marine fishes of continental Ecuador, Tomo II. Quito, IMBIOE/NAZCA/IFEA, T 2.

Krebs, C. J. 1999. Ecological methodology. 2nd ed. Menlo Park, California, Addison Wesley Longman, 620p.

Lasso, C. A., R. S. Rosa, P. Sánchez-Duarte, M. A. MoralesBetancourt \& E. Agudelo-Córdoba (Eds). 2013. Rayas de agua dulce (Potamotrygonidae) de Suramérica. Parte I. Colombia, Venezuela, Ecuador, Perú, Brasil, Guyana, Surinam y Guayana Francesa: diversidad, bioecología, uso y conservación. Bogotá, D. C., Colombia, Instituto de Investigaciones de Recursos Biológicos Alexander von Humboldt (IAvH), 368 p, i II (Serie Editorial Recursos Hidrobiológicos y Pesqueros Continentales de Colombia. Serie Recursos Hidrobiológicos y Pesqueros Continentales de Colombia, IX).

Last, P. R. \& G. K. Yearsley. 2002. Zoogeography and relationships of Australasian skates (Chondrichthyes: Rajidae). Journal of Biogeography, 29: 1627-1641.

Last, P. R. \& W. T. White. 2011. Biogeographic patterns in the Australian chondrichthyan fauna. Journal of Fish Biology, 79: 1193-1213.

Lim, D. D., P. Motta, K. Mara \& A. P. Martin. 2010. Phylogeny of hammerhead sharks (Family Sphyrnidae) inferred from mitochondrial and nuclear genes. Molecular Phylogenetics and Evolution, 55: 572-579. 
López-García, J., A. F. Navia, P. A. Mejía-Falla \& E. A. Rubio. 2012. Feeding habits and trophic ecology of Dasyatis longa (Elasmobranchii: Myliobatiformes): sexual, temporal and ontogenetic effects. Journal of Fish Biology, 80: 1563-1579.

McEachran, J. D. \& N. Aschliman, N. 2004. Phylonegy of batoidea Pp. 79-113. In: Carrier, J. C., J. A. Musick \& M. R. Heithaus (Eds.). Biology of sharks and their relatives. Boca Ratón, CRC Press, (CRC marine biology series).

Mejía-Falla, P. A., E. Cortés, A. F. Navia \& F. A. Zapata. 2014a. Age and growth of the round stingray Urotrygon rogersi, a particularly fast-growing and short-lived Elasmobranch. PloS ONE, 9(4): e96077.

Mejía-Falla, P. A. \& A. F. Navia. 2011. Relationship between body size and geographic range size of elasmobranchs from the Tropical Eastern Pacific: an initial approximation for their conservation. Ciencias Marinas, 37: 305-321.

Mejía-Falla, P. A., A. F. Navia \& E. Cortés. 2012. Reproductive variables of Urotrygon rogersi (Batoidea: Urotrygonidae): a species with a triannual reproductive cycle in the Eastern Tropical Pacific Ocean. Journal of Fish Biology, 80: 1246-1266. Mejía-Falla, P. A., A. F. Navia, R. Lozano, A. Tobón-López, K. Narvaez, L. A. Muñoz-Osorio, L. M. Mejía-Ladino \& J. López-García. 2014b. Uso de hábitat de Triaenodon obesus (Carcharhiniformes: Carcharhinidae), Rhincodon typus (Orectolobiformes: Rhincodontidae) y Manta birostris (Myliobatiformes: Myliobatidae) en el Parque Nacional Natural Isla Gorgona, Pacífico colombiano. Revista de Biología Tropical, 62(suppl. 1): 329-342.

Mejía-Falla, P. A., A. F. Navia \& V. Puentes (Eds.). 2011. Guía para la identificación de especies de tiburones, rayas y quimeras de Colombia. Bogotá, D.C., Colombia, Ministerio de Ambiente y Desarrollo Sostenible; Corporación para el Desarrollo Sostenible del Archipiélago de San Andrés, Providencia y Santa Catalina - CORALINA; Gobernación de San Andrés, Providencia y Santa Catalina, Fundación SQUALUS, 350p.

Mejía-Falla, P. A., A. F. Navia, L. M. Mejía-Ladino, A. Acero P. \& E. A. Rubio. 2007. Tiburones y rayas de Colombia (Pisces: Elasmobranchii): lista actualizada, revisada y comentada. Boletín de Investigaciones Marinas y Costeras, 36: 111-149.

Musick, J. A., M. M. Harbin \& L. J. V. Compagno. 2004. Historical zoogeography of the Selachii. Pp. 33-78. In: Carrier, J. C., J. A. Musick \& M. R. Heithaus (Eds.). Biology of sharks and their relatives. Boca Ratón, CRC Press, (CRC marine biology series).

Navia, A. F., E. Cortés \& P. A. Mejía-Falla. 2010. Topological analysis of the ecological importance of elasmobranch fishes: A foodweb study on the Gulf of Tortugas, Colombia. Ecological Modelling, 221: 2918-2926.

Navia, A. F., P. A. Mejía-Falla \& A. Giraldo. 2007. Feeding ecology of elasmobranch fishes in coastal waters the central fishing zone of the Colombian Eastern Tropical Pacific. BMC Ecology, 7: 8(10p.).

Navia, A. F., A. Torres., P. A. Mejía-Falla \& A. Giraldo. 2011. Sexual, ontogenetic, temporal and spatial effects on the diet of Urotrygon rogersi (Elasmobranchii: Myliobatiformes). Journal of Fish Biology, 78: 1213-1224.
Nei, M. \& S. Kumar. 2000. Molecular evolution and phylogenetics. Oxford; New York, Oxford University Press, 333p.

Nelson, J. S. 2006. Fishes of the World. $4^{\text {th }}$ ed. Hoboken, NJ, J. Wiley, 601p.

Parks, D. H., M. Porter, S. Churcher, S. Wang, C. Blouin, J. Whalley, S. Brooks \& R. Beiko. 2009. GenGIS: a geospatial information system for genomic data. Genome Research, 19: 1896-1904.

Payán, L. F., A. F. Navia., E. A. Rubio \& P. A. Mejía-Falla. 2011. Biología de la raya guitarra Rhinobatos leucorhynchus (Günther, 1867) (Rajiformes: Rhinobatidae) en el Pacífico colombiano. Latin American Journal of Aquatic Research, 39: 286-296.

Pielou, E. C. 1979. Biogeography. New York, J. Wiley, 351p.

Pitman III, W. C., S. C. Cande, J. L. LaBrecque \& J. Pindell. 1993. Fragmentation of Gondwana: the separation of Africa from South America. Pp. 15-34. In: Goldblatt, P. (Ed.). Biological relationships between Africa and South America. New Haven, Yale University Press.

Ratnasingham, S. \& P. D. N. Hebert. 2007. BOLD: the Barcode of Life Data System (www. barcodinglife.org). Molecular Ecology Notes, 7: 355-364.

Robertson, D. R. \& G. R. Allen. 2008. Shorefishes of the Tropical Eastern Pacific: online information system. Smithsonian Tropical Research Institute, Balboa, Panamá. Available: http://biogeodb. stri.si.edu/sftep/es/pages. (12 November 2015).

Schultz, J. K., K. A. Feldheim, S. H. Gruber, M. V. Ashley, T. M. McGovern \& B. W. Bowen. 2008. Global phylogeography and seascape genetics of the lemon sharks (genus Negaprion). Molecular Ecology, 17: 5336-5348.

Sequeira, A. M., C. Mellin, M. G. Meekan, D. W. Sims \& C. J. Bradshaw. 2013. Inferred global connectivity of whale shark Rhincodon typus populations. Journal of Fish Biology, 82: 367-389.

Smith, S. A. \& E. Bermingham. 2005. The biogeography of lower Mesoamerican freshwater fishes. Journal of Biogeography, 32: 1835-1854.

Springer, V. G. 1982. Pacific plate biogeography, with special reference to shorefishes. Washington D.C., Smithsonian Institution Press, 182p. (Smithsonian Contributions to Zoology, 367).

Stelbrink, B., T. von Rintelen, G. Cliff \& J. Kriwet. 2010. Molecular systematics and global phylogeography of angel sharks (genus Squatina). Molecular Phylogenetics and Evolution, 54: 395404.

Tamura, K., G. Stecher, D. Peterson, A. Filipski \& S. Kumar. 2013. MEGA6: Molecular Evolutionary Genetics Analysis version 6.0. Molecular Biology and Evolution, 30: 2725-2729.

White, W. T. \& P. R. Last. 2012. A review of the taxonomy of chondrichthyan fishes: a modern perspective. Journal of Fish Biology, 80: 901-917.
Submitted September 08, 2014 Accepted March 08, 2016 by Luiz Rocha 